\title{
Apoptosis in SIV infection
}

\author{
B Hurtrel ${ }^{1,4}$, F Petit ${ }^{1}$, D Arnoult ${ }^{1}$, M Müller-Trutwin ${ }^{2}$, G Silvestri ${ }^{3}$ \\ and $\mathrm{J}$ Estaquier ${ }^{\star, 1}$ \\ ${ }^{1}$ Unité de Physiopathologie des Infections Lentivirales, Institut Pasteur, Paris, \\ cedex 15, France \\ ${ }^{2}$ Unité de Biologie des Rétrovirus, Institut Pasteur, Paris, France \\ ${ }^{3}$ Emory Vaccine Center, 954 Gatewood Rd NE, Atlanta, GA, USA \\ ${ }^{4}$ This work is dedicated to the memory of Bruno Hurtrel \\ * Corresponding author: J Estaquier, Unite de physiopathologie des infections \\ lentivirales, Institut Pasteur, 28 rue du Dr roux, Paris, France. \\ Tel: + 331456889 15; Fax: + 331406134 50; \\ E-mail: jestaqui@pasteur.fr
}

Received 24.11.04; revised 03.1.05; accepted 04.1.05; published online 01.4.05 Edited by $\mathrm{G}$ Kroemer

\begin{abstract}
Pathogenic human immunodeficiency virus (HIV)/Simian immunodeficiency virus (SIV) infection is associated with increased T-cell apoptosis. In marked contrast to HIV infection in humans and SIV infection in macaques, the SIV infection of natural host species is typically nonpathogenic despite high levels of viral replication. In these nonpathogenic primate models, no observation of T-cell apoptosis was observed, suggesting that either SIV is less capable of directly inducing apoptosis in natural hosts (likely as a result of coevolution/coadaptation with the host) or, alternatively, that the indirect T-cell apoptosis plays the key role in determining the HIV-associated T-cell depletion and progression to acquired immune deficiency syndrome (AIDS). Understanding the molecular and cellular mechanisms responsible for the disease-free equilibrium in natural hosts for SIV infection, including those determining the absence of high levels of T-cell apoptosis, is likely to provide important clues regarding the mechanisms of AIDS pathogenesis in humans.

Cell Death and Differentiation (2005) 12, 979-990.

doi:10.1038/sj.cdd. 4401600

Published online 1 April 2005
\end{abstract}

Keywords: SIV; primates; apoptosis; CD4; pathogenesis

Abbreviations: HIV, human immunodeficiency virus; SIV, Simian immunodeficiency virus; SHIV, Simian-human immunodeficiency virus; AIDS, acquired immune deficiency syndrome; NHPs, African non-human primates; SMs, sooty mangabeys; AGMs, African green monkeys; $\mathrm{LNs}$, lymph nodes; FDC, follicular dendritic cells; HAART, highly active antiretroviral therapy; DISC, deathinducing signaling complex; zVAD-fmk, z-Val-Ala-Asp-fmk.

\section{Non-human Primate (NHP) Models for HIV Infection and AIDS}

The family of CD4 + T-lymphotropic primate lentiviruses is comprised of two human viruses (human immunodeficiency virus type 1 (HIV-1) and 2 (HIV-2)) and as many as 27 distinct simian immunodeficiency viruses (SIVs) found naturally in African non-human primates (NHPs) ${ }^{1}$ (Figure 1a). The pathogenesis of HIV-1 infection is a complex, multifactorial process that depends on multiple, dynamic viral and host factors. The depletion of CD4 ${ }^{+} \mathrm{T}$ cells is a major determinant of pathogenicity in HIV-1 infection. In HIV-infected patients, CD4 T-cell depletion is associated with high viral turnover, ${ }^{2}$ chronic generalized immune system activation, ${ }^{3-5}$ and progressive loss of T-cell-mediated immunity. ${ }^{6}$

Several studies have found that HIV originally resulted from multiple episodes of zoonotic transmission to humans of CD4tropic lentiviruses circulating in NHPs. ${ }^{1}$ SIVs were shown to cluster in at least six major, approximately equidistant lineages. ${ }^{7,8}$ HIV-1 and HIV-2 belong to two of these clusters and emerged most likely following transmissions of, respectively, SIVcpz from chimpanzees and SIVsm from sooty mangabeys (SMs). ${ }^{9-13}$ The remaining clusters are formed by SIVs isolated from African green monkeys (AGMs), Syke's monkeys, l'hoest monkeys, and colobus monkeys.,14-21 AGMs (Cercopithecus aethiops), due to their numbers and wide geographical distribution in sub-Saharan Africa, represent the largest single reservoir of SIV (SIVagm), as upwards of $50 \%$ of wild monkeys are infected with the virus. The phylogeny of many SIVs resembles that of their host species, suggesting a coevolution. ${ }^{11,14,22}$ In contrast to these, some viruses (SIVrcm, SIVagm.sab, SIVmnd-2, and SIVdrl) cluster in different lineages according to the genomic region analyzed. ${ }^{23-26}$ These viruses most likely result from recombination events in monkeys dually infected by SIVs of two distinct lineages.

Natural hosts for SIV generally do not show any signs of acquired immune deficiency syndrome (AIDS) despite chronic sustained levels of viral replication. ${ }^{27-32}$ Indeed, the development of AIDS has been observed in only one SM and in one mandrill, after a 18-year-incubation, exceeding the normal lifespan of wild primates. ${ }^{33,34}$ Similar to humans and macaques, naturally or experimentally infected SMs, AGMs, and mandrills show viremia levels which are highly variable among the individual monkeys, but in many of them the plasmatic viral RNA levels are persistently as high or even higher than those known with progression in humans. ${ }^{27-29,31,32,34,35}$ Studies of two subspecies (sabaeus and vervet) of naturally SIV-infected AGMs analyzed during the chronic phase shows signs of viral replication in the same tissues as during pathogenic infections, including gut and thymus. ${ }^{29,35,36}$ Both T CD4 + lymphocytes and macrophages are infected. ${ }^{29}$ In two naturally SIV-infected SMs, the number of virus replicating cells in lymph nodes (LNs) was similar to what has been observed in macaques and humans progressing to AIDS. ${ }^{28}$ Lower numbers of viral DNA and RNA copy numbers were however observed in chronically infected AGMs as compared to pathogenic SIVmac and HIV infections. ${ }^{31,37}$ Both SIVagm and SIVsm infection are 


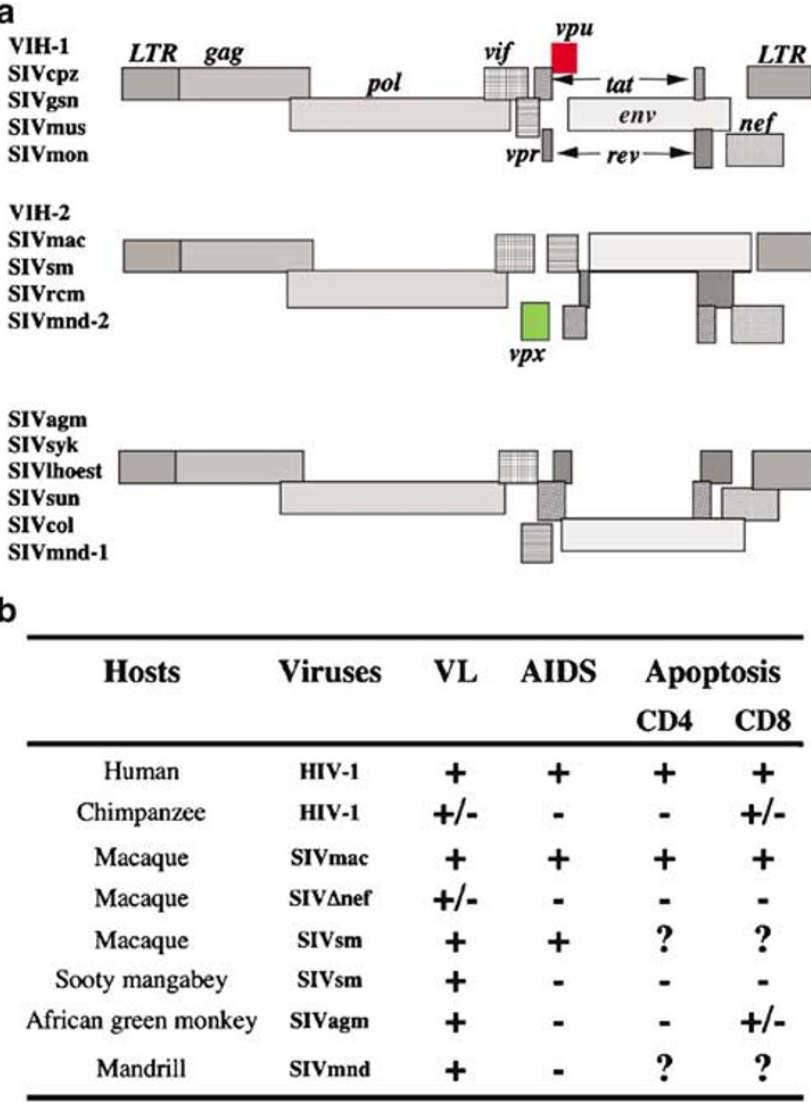

Figure 1 Human and non-human primate (NHP) models. (a) The family of lymphotropic primate lentiviruses comprise large numbers of human (HIV) and simian immunodeficiency viruses (SIVs) found naturally in NHPs. They present three distinct genomic organization of which two are identical to HIV-1 and HIV-2. (b) The depletion of $\mathrm{CD}^{+}{ }^{+} \mathrm{T}$ cells is a major determinant of pathogenicity. Experimental primate models reveal a relationship between CD4 T-cell apoptosis and further progression towards AIDS

characterized by a low or absent viral trapping by follicular dendritic cells (FDC) in LN germinal centers. Importantly, accidental or experimental transmission of SIV from natural hosts, that is, SMs and AGMs, to Asian non-natural NHP host species, such as pigtailed and rhesus macaques, is followed by development of AIDS. ${ }^{38,39}$ Similarly, SIVIhoest, which is genetically close to SIVmnd-1 and is also associated with asymptomatic infection in its natural host, appears to induce AIDS when inoculated in macaques. ${ }^{40}$ Collectively, these studies demonstrate that the absence of major CD4 T-cell depletion and AIDS in natural hosts for SIV infection is not due to intrinsic lack of viral pathogenicity, but that host-specific factors play a crucial role in protection from disease progression. In addition, these studies provide evidence that the nonpathogenic nature of SIV infection in the natural host is likely to be not related to a more effective host control over viral replication. However, the exact molecular mechanisms underlying the lack of any AIDS-related illness in natural hosts for SIV infection are still unknown.

\section{T-cell Apoptosis and AIDS}

T-cell apoptosis (Figure 2) may be one of the mechanisms that is responsible for T-cell depletion during HIV and SIV

infections. Several studies have found that abnormal levels of apoptosis occur both in vitro ${ }^{41-51}$ and in vivo ${ }^{52,53}$ in CD4 ${ }^{+}$ and $\mathrm{CD}^{+}{ }^{+} \mathrm{T}$ cells from HIV-1-infected persons. Importantly, the majority of $\mathrm{T}$ cells undergoing apoptosis in HIV-infected patients are not infected by the virus; ${ }^{52,53}$ this observation led to the definition of 'bystander' apoptosis when referring to apoptosis that is not occurring as a direct cytopathic effect of HIV. Clinical studies have revealed that HIV-1 and HIV-2 differ in their natural course of infection. Thus, HIV-2 is characterized by higher CD4 counts, low level of viremia, and low transmission rate. $^{54}$ It has been reported that the low pathogenicity of HIV-2 is associated with a lower immune activation and a lesser degree of CD4 T-cell apoptosis. ${ }^{55}$ Importantly, the magnitude of $\mathrm{CD}^{+}{ }^{+}$T-cell apoptosis observed in HIV-infected individuals correlates well with the stage of HIV disease. ${ }^{56-61}$ In addition, changes in the levels of T-cell apoptosis after highly active antiretroviral therapy (HAART) predict the immunological response (i.e., increase in CD4 T-cell count), thus confirming the link between disease progression and apoptosis. ${ }^{62-64}$ Taken together, these observations indicate that the increased susceptibility to apoptosis of $\mathrm{T}$ lymphocytes from HIV-infected individuals is a marker of HIV disease progression and support the hypothesis that the chronic immune system activation that

\section{Extrinsic pathway}

Death-receptor dependent

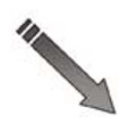

Members of the Bcl-2 family

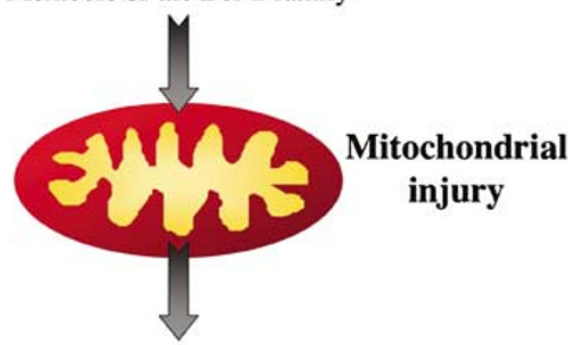

Release of Apoptogenic Mitochondrial Factors

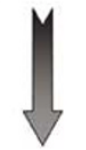

Chromatin condensation and fragmentation

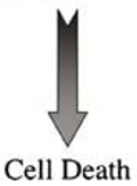

Figure 2 Overview of apoptosis pathway. Ligation of the death receptors ('extrinsic pathway') leads to the activation of the proapoptotic member of the Bcl2 family, Bid, generating a truncated Bid (tBid). tBid tranlocates to the mitochondria where it acts with the proapoptotic Bax and Bak. The 'intrinsic pathway' is induced after apoptotic insults (for drugs, UV, growth factor deprival, etc.) leading to Bax and Bak activation and in turn induced mitochondrial membrane permeabilization ( $\Delta \Psi_{\mathrm{m}}$ loss). Mitochondria insult is manifested by the release of apoptogenic factors into the cytosol leading to chromatin condensation and fragmentation and cell death (for a review, see Petit et al. ${ }^{190}$ ) 
follows HIV infection could be one of the mechanism responsible for this cell death process. ${ }^{27,30,52}$

The primary acute phase of human (HIV) and simian (SIV) immunodeficiency virus infection is characterized by an early burst in viral replication, which results in an exponential increase in plasma viral load and the dissemination and seeding of the virus in all the peripheral lymphoid organs. ${ }^{65-69}$ Following the induction of the host humoral and cellular immune response to the virus, a steady-state plasma viral load level is reached at the end of this primary phase, around 2-6 months after infection in macaques and in humans; the level of set-point viral replication predicts the progression towards disease, ranging from rapid development of AIDS to long-term slow progressive infection. ${ }^{70-73}$ Recent findings support a dynamic model of pathogenesis in which the extent of apoptosis induced during the primary phase of SIV infection is predictive of the subsequent rapid or slow progression towards AIDS. ${ }^{74}$ Furthermore, the extent of apoptosis in peripheral lymph nodes is greater in primates infected with a pathogenic SIV strain than in those infected with an attenuated, nef-deleted SIV. ${ }^{75}$ Another study identified an early induction of apoptosis in thymic T-cell precursors (followed by a subsequent increase in cell cycling) in macaques infected with pathogenic SIV; this effect was lacking in the same macaque species infected with the nefdeleted SIV. ${ }^{76}$ The fact that apoptosis in the thymus as well as in the LNs of macaques infected with pathogenic SIV occurs in both infected and uninfected $T$ cells indicates again that mechanisms other than the direct cytopathic effect of HIV are involved in this disease process. ${ }^{53,77}$

Furthermore, studies performed in pathogenic and nonpathogenic primate models of HIV or SIV infection during the chronic asymptomatic phase have identified a correlation between the induction of enhanced in vitro T-cell apoptosis and the in vivo pathogenic nature of the retroviral infection $^{27,44,51,78-84}$ (Figure 1b). Thus, enhanced levels of apoptosis in CD4 ${ }^{+}$T cells were observed in HIV-1-infected human individuals, rhesus macaques infected with a pathogenic strain of SIVmac, and chimpanzees infected with a pathogenic strain of SIVcpz leading to AIDS, ${ }^{78,85}$ while enhanced CD8 T-cell apoptosis was observed in both pathogenic and nonpathogenic primate models. In contrast, no increased propensity of either CD4 + or CD8 + T-cell in vitro apoptosis and normal levels of T-cell apoptosis in the Tcell-dependent areas of the LN were observed in either naturally or experimentally SIV-infected SMs. ${ }^{27}$ Altogether, these reports suggest that the capacity to induce apoptosis during primary SIV infection is a feature that does not depend solely on the genetic makeup of the virus itself, but is related to specific features of the host-virus interaction; these features will then play a key role in determining the potential for a given virus to induce AIDS in a specific host species.

\section{Extrinsic and Intrinsic Programmed Cell Death Pathways and AIDS}

\section{Activation-induced cell death}

The increased level of T-cell apoptosis observed in HIVinfected human individuals is associated with enhanced expression of the CD95/Fas receptor and its ligand (CD95L) (Figure $3 a$ ), and increased sensitivity of $T$ cells to apoptosis mediated by CD95/Fas ligation using either agonistic CD95 monoclonal antibodies or recombinant CD95L. ${ }^{48-50,86-94}$ Other members of the TNF-receptor ligand family (TRAIL, TNF- $\alpha$ ) have also been implicated in the increased T-cell apoptosis seen in HIV-1-infected individuals. ${ }^{95-100}$ Similarly, $\mathrm{T}$ cells from macaques infected with a pathogenic strain (SIVmac251) are more prone to undergo apoptosis following ligation of CD95/Fas than the other death receptors. ${ }^{101}$ Moreover, in HIV-infected individuals and SIV-infected macaques, increased CD95/Fas sensitivity of CD8 + T cells did not correlate with plasma viral load. ${ }^{102}$

Ligation of CD95/Fas by its counterpart CD95L induces the aggregation of several proteins from the death-inducing signaling complex (DISC) leading to the activation of the initiator caspase-8. ${ }^{103}$ Once activated, caspase-8 can trigger activation of downstream effector caspases (i.e., caspases 3 , 6 , and 7), which can be modulated by the caspase inhibitor zVAD-fmk (z-Val-Ala-Asp-fmk). However, an alternative pathway, independent to the caspase-8, involving the kinase RIP and inducing a necrotic type of cell death that is not prevented by $z V A D-f m k$ has also been reported. ${ }^{104}$ In macaque as well as in humans, zVAD-fmk prevents CD95-mediated T-cell death, indicating that a RIP-dependent pathway of T-cell death is not a prominent factor under these circumstances. ${ }^{49,101}$ Interestingly, the enhancement in CD95mediated T-cell death in rhesus macaques is not associated with either an upregulation of caspase- 3 and caspase- 8 or a decrease of FLIP-L and FLIP-S. Similarly, Badley et al. ${ }^{105}$ found that death of $T$ cells from HIV-infected individuals was not associated with a change in the amount of FLIP. T-cell activation occurring in the course of immune responses has been shown to increase sensitivity to CD95-induced apoptosis. Antiretroviral therapy is followed by a significant decrease in CD95-induced, activation-induced, and spontaneous apoptosis in ex vivo cultured peripheral blood lymphocytes ${ }^{60,96}$ which correlates with decreased immune activation. ${ }^{105}$ Thus, effective viral suppression decreases immune activation and apoptosis, thereby contributing to immune reconstitution.

\section{Death by neglect}

Activated lymphocytes can undergo death by neglect after antigen and inflammatory cytokine stimulations and those dying cells are cleared at the end of an immune response. Cell death as a result of neglect occurs after the loss of mitochondrial homeostasis. ${ }^{106}$ Spontaneous apoptosis during infection is associated with a loss of mitochondrial transmembrane potential $\left(\Delta \Psi_{\mathrm{m}}\right)$, suggesting that changes in mitochondrial permeability could be a central event in the regulation of T-cell death in HIV-infected individuals ${ }^{107}$ (Figure 3b). Recently, we found that spontaneous $\mathrm{T}$-cell death of pathogenic SIVmac251-infected macaques was not prevented by zVADfmk. ${ }^{101}$ Thus, although caspase activation was occurring in the course of spontaneous apoptosis, it was dispensable for cell killing. Bim is required for efficient death-by-neglect, as Bim-/- mice have lymphoid hyperplasia and lymphocytes display partial resistance to death-by-neglect. ${ }^{108,109}$ The cell death observed in multiple tissues of $\mathrm{Bcl}-2-/-$ mice also 


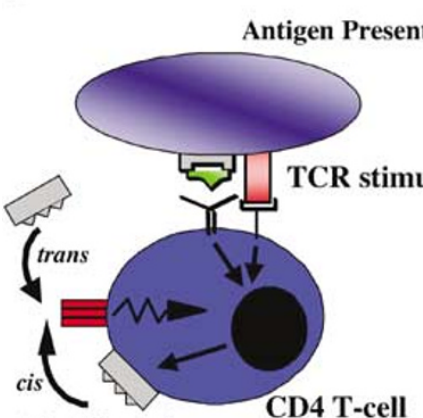

Fas Ligand

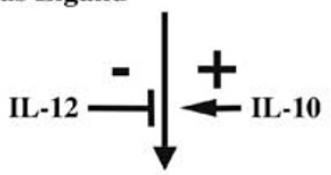

Apoptosis

B Hurtrel et al

(1)

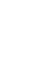

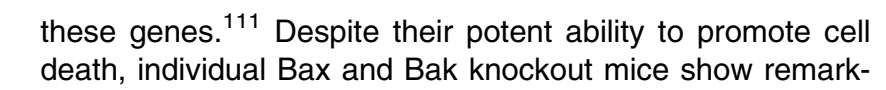
ably little changes in the immune phenotype. Bax-deficient mice have mild lymphoid hyperplasia and Bak-deficient mice have no discernable phenotype. ${ }^{112}$ In contrast, combined deficiency of both Bax and Bak results in the appearance of multiple phenotypes, in the immune system as well as in other organs. ${ }^{113}$

In chronic SIVmac251-infected macaques, T-cell apoptosis was not associated with an increase in Bax expression. Our findings do not, however, exclude the possibility that SIV infection favors the translocation of Bax from the cytosol to the mitochondria. This phenomenon has been reported in other cell types in response to growth factor deprivation. ${ }^{114,115}$ In fact, a clear increase in the levels of two other proapoptotic proteins, Bak and BimL, was observed. The increased levels of these proteins in SIV-infected monkeys suggest that the upregulation of Bak and Bim may be involved in the loss of $\psi_{\mathrm{m}}$ loss and spontaneous T-cell death. However, the mechanisms involved in the changes of Bim and Bak expressions upon SIV infection remain unknown.

\section{b Neglected T cell death}

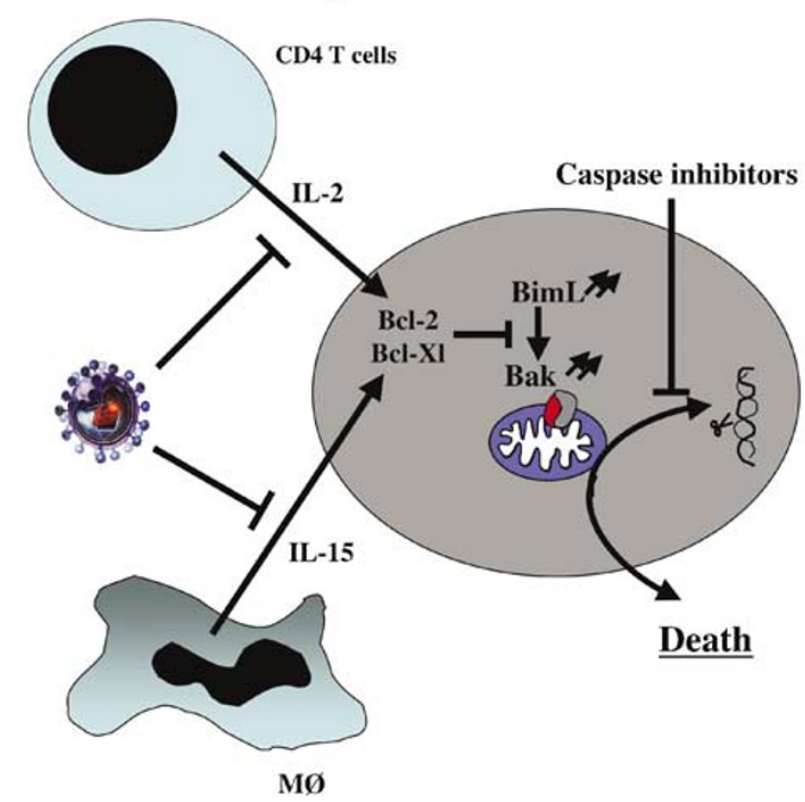

Figure 3 Indirect mechanisms that mediate programmed cell death or apoptosis during SIV infection. (a) Activation-induced cell death: Restimulation of activated T cells induces death at least in part through a CD95/Fas pathway in $\mathrm{CD} 4{ }^{+} \mathrm{T}$ cells. Cytokines exert either a positive (IL-12) or negative (IL-10) effect on CD4 T-cell apoptosis. (b) Neglected cell death: Members of the Bcl-2 family regulate cell death. Upregulation of Bim and Bak-mediated mitochondrial membrane potential lossleads to the release of apoptogenic factors from the mitochondria into the cytosol. In this form of cell death, caspase inhibitor (zVADfmk) prevented apoptotic phenotype (chromatin condensation and fragmentation) but did not prevent subsequent cell death. Cytokines, in contrast, prevented both the apoptotic phenotype and the cell death by preserving mitochondrial membrane potential

requires Bim activity, because Bim deficiency can rescue some aspects of Bcl-2-deficiency. ${ }^{110}$ The role of Bax and Bak in the regulation of death-by-neglect and loss of mitochondrial homeostasis has also been demonstrated in mice deficient in

\section{Preventive effect of cytokines}

Consistent with the idea that costimulatory signals expressed by accessory cells play a key role in the control of T-cell survival and T-cell death during HIV infection, we and others have found that cytokines exert a preventive effect on T-cell death of HIV-infected individuals. ${ }^{46,48,49,102,116-122}$ Thus, the addition of antibodies to IL-10 or the addition of IL-12 have a preventive effect on abnormal programmed cell death induction in response to in vitro stimulation in HIV-infected persons. ${ }^{46,48}$ Moreover, we found that IL-12, which upregulates TH1 functions and prevents TCR-mediated CD4 T-cell apoptosis, also prevents Fas-mediated apoptosis of CD4 + T cells from HIV-infected persons. ${ }^{48}$ In contrast, IL-10 prevents Fas-mediated apoptosis of CD8 + T cells from HIV-infected persons while having no preventive effect on CD4 T-cell death. ${ }^{49} \mathrm{IL}-2$, a cytokine secreted by activated $\mathrm{T}$ cells and involved in cell-mediated immunity, had a preventive effect on Fas-mediated death of both CD4 + and CD8 + T cells. IL-15 can also inhibit T-cell apoptosis and enhances the function of HIV-specific CD8 + T cells. Similarly, IL-2 and IL-15 reduced the death rate of CD4 + and CD8 + T cells from SIVmac251infected macaques following spontaneous apoptosis and induction by Fas ligation, while IL-10 only prevents CD8 Tcell death. ${ }^{101}$ Therefore, the relative contribution other than overwhelming, direct-virus-mediated destruction might also be operative for the role of lymphoid microenvironment (IL-15, $\mathrm{IL}-12$, and IL-10 are produced by macrophages). Thus, the destruction of such support, concomitant with the loss of CD4 + T cells, could impaire T-cell immune response.

\section{Cell cycle dysregulation}

Peripheral blood lymphocytes isolated from HIV-infected patients show complex perturbation of cell cycle control, consisting mainly of (i) increased intracellular levels of cyclin B1 with consequent inappropriate activation of the p34 cdc2 kinase, and (ii) abnormal nucleolar structure, as shown by 
staining for the argyrophilic Nucleolar Organizing Regions (AgNOR) and the subcellular localization of nucleolin in confocal microscopy. ${ }^{122-127}$ Importantly, the HIV-associated cell cycle dysregulation is exacerbated by in vitro treatment with mitogens and appears to be correlated with induction of T-cell apoptosis; ${ }^{122,123,126}$ however, these cell cycle perturbations and apoptosis are reduced after exogenous administration of IL-2 in vitro. ${ }^{122}$ In mitogen-activated lymphocytes from HIV-infected patients, the inappropriate activation of the cyclin B1/p34 cdc2 kinase complex is temporally associated with increased threonine phosphorylation, augmented fragmentation, and prominent extranuclear and cell surface localization of nucleolin. ${ }^{127}$ It is of note that increased lymphocyte apoptosis is observed at the time of cell surface localization of nucleolin. Interestingly, a recent comparative study of cell cycle dysregulation in two models of pathogenic (i.e. rhesus macaques) and nonpathogenic (i.e., SMs) SIV infection has shown that a variety of cell cycle perturbations is observed in apoptosis-sensitive $T$ cells derived from the peripheral blood and lymph nodes of macaques infected with SIV and progressing to AIDS, while normal cell cycle regulation is observed in apoptosis-resistant $\mathrm{T}$ cells from naturally SIVinfected SMs that do not progress to AIDS. ${ }^{128}$ Taken together, these findings suggest that during pathogenic HIV and SIV infections (but not during nonpathogenic SIV infection of natural hosts), the presence of cell cycle dysregulation is involved in determining the abnormal susceptibility to apoptosis of T lymphocytes. ${ }^{124}$

\section{The Interaction between the Envelope Glycoprotein and CD4/coreceptors is a Crucial Factor in the Pathogenesis of AIDS}

HIV-1 infection can cause apoptosis via a variety of mechanisms, some of which rely directly on the intricate interaction between the virus and the host cells, and some of which act indirectly through activation of the host's inflammatory reaction and immune system activation. Despite intensive investigations, several important questions remain about the mechanisms through which HIV infection directly induces CD4 T-cell apoptosis. Although direct in vitro cytopathic effect of HIV and SIV strains is a well-established phenomenon, it is unclear what is the relevance of this direct cytopathic effect in the context of in vivo viral replication. Indeed, a very intriguing feature of nonpathogenic SIV infections, such as those in SMs, AGMs, and mandrills, is that CD4 T-cell depletion and AIDS do not arise despite in vitro cytopathicity and levels of viremia that can be as high or higher than those observed in the HIV-infected humans and SIV-infected macaques. ${ }^{27-32}$ Thus, virus-host cell-specific interactions have been proposed as significant contributors to the development of aberrant signaling events and progressive immunodeficiency. ${ }^{53}$

The envelope glycoprotein complex (Env) appears to be one of the dominant apoptosis-inducing molecules encoded by the HIV-1 genome (Figure 4). The gp120 is present on the surface of infected T cells, on viral particles, or as a soluble protein $^{129,130}$ and can bind to and crosslink CD4. The interaction of the gp 120 with the CD4 molecule can prime CD4 + and CD8 + T cells for apoptosis, ${ }^{95,131-135}$ and can promote cell-to-cell fusion leading to syncytia formation that can undergo apoptosis. This apoptosis is characterized by the translocation of Bax from the cytosol to mitochondria leading to the mitochondrial membrane permeabilization with loss of the $\Delta \Psi_{\mathrm{m}}$ ), release of apoptogenic intermembrane proteins, in particular apoptosis-inducing factor and cytochrome $c$, caspase activation, and nuclear chromatin condensation. ${ }^{136}$ In vitro studies have also identified a positive correlation between CD4 T-cell depletion and infection by syncytium inducing HIV $-1^{137,138}$ or SIV variants. ${ }^{75,139-141}$ In addition, multinucleated giant cells, a pathological hallmark of AIDS encephalopathy are also found during SIV-encephalitis ${ }^{142,143}$ and these cells revealed DNA fragmentation. ${ }^{144}$ The HIV envelope protein has also been reported to cause apoptosis by binding to a chemokine coreceptor. ${ }^{145-148}$ Several studies have indicated that macrophages are capable to trigger apoptosis of uninfected bystander $\mathrm{CD}^{+}$and $\mathrm{CD}^{+}{ }^{+} \mathrm{T}$ cells. ${ }^{149}$ Apoptosis involve the interaction between several death receptors (Fas, TNF-R, TRAIL-R) and their counterparts, their death ligands. ${ }^{96,100,102,150-153}$ As tissue macrophages from HIV-infected individuals have been shown to harbor the virus and have the potential to act as reservoirs of virions, the role of macrophages in inducing T-cell death in vivo merit to be further explored in particular regarding pathogenic and nonpathogenic primate models of AIDS. Recently, it has been also observed that incubation of resting $\mathrm{CD}^{+}{ }^{+} \mathrm{T}$ cells from healthy donors with HIV, even in the presence of an inhibitor of the viral replication, is sufficient to prime CD4 ${ }^{+}$T cells for apoptosis. ${ }^{154,155}$ Therefore, as most of the HIV particles produced are noninfectious, the simple fixation and/or penetration of viruses, without integration, may be sufficient to prime T cells for apoptosis in quiescent cells.

Several studies have suggested a link between coreceptors usage and disease progression in HIV-infected individuals. The role of CCR5 in transmission has been highlighted by the protective effect of a 32-bp deletion in CCR5 (CCR5 $\Delta 32)$ that results in a truncated molecule that is not expressed at the cell surface. ${ }^{156-158}$ Individuals homozygous for CCR5 $\Delta 32$ are resistant to HIV-1 infection, whereas the disease progresses slowly in individuals who are heterozygous for this mutation. ${ }^{159-161}$ Other studies have shown that the proportion of $\mathrm{T}$ cells expressing CCR5 differs greatly between individuals and increases chronically in HIV-infected individuals during disease progression, ${ }^{162,163}$ and others have shown that the cell surface density of CCR5 correlates positively with disease progression. ${ }^{164,165}$ It has been also reported that T-cell depletion in peripheral blood during primary infection was related to T cells expressing CCR5. ${ }^{166-168}$ However, this latter observation remains controversial. ${ }^{169}$

Since HIV-1 does not replicate efficiently in non-human primate species, chimeric simian-human immunodeficiency viruses (SHIVs) have been created that can infect NHPs. SHIVs contain HIV-1-derived segments encoding the viral envelope glycoproteins and the Tat, Rev, and Vpu regulatory proteins in an SIV background. ${ }^{170}$ A SHIV containing the envelope glycoproteins of a primary HIV-1 isolate, 89.6, replicated efficiently in rhesus monkeys but did not deplete CD4 ${ }^{+}$T lymphocytes or induce disease in these animals. ${ }^{171}$ 
a

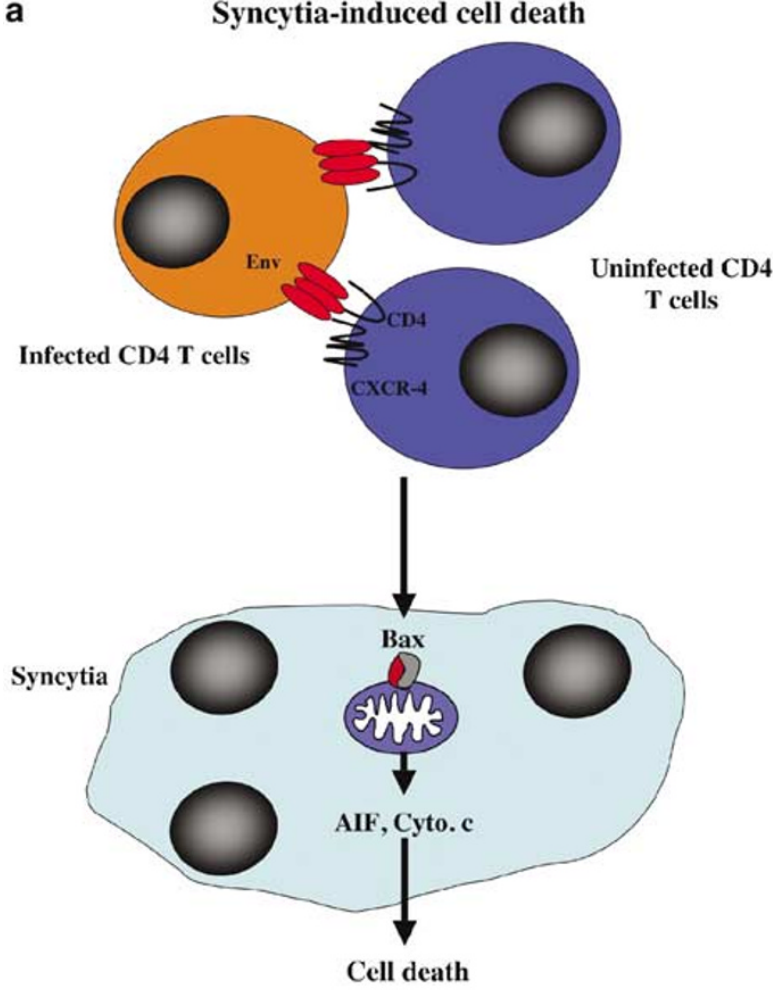

b

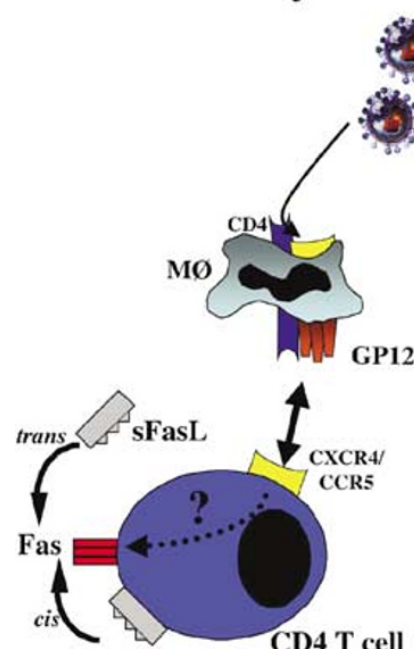

FasL
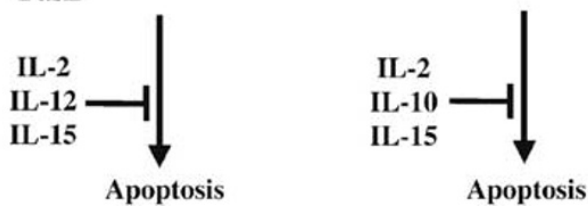

Figure 4 Coreceptor engagment-mediated T-cell apoptosis. (a) Syncytia induced cell death: Cell-to-cell fusion leads to syncytia formation that induces Bax upregulation and translocation to the mitochondria and subsequent release of apoptogenic factors and cell death. (b) Bystander cell death: The envelope glycoprotein interacts with the CD4 receptor at the cell membrane and subsequently with the coreceptor (CXCR4/CCR5). This interaction induces signal transduction leading to CD95/Fas sensitization. Fas ligand (FasL/CD95L), in cis or in trans, induces cell death. Environmental factors like cytokines prevent CD95-ligation-mediated cell death
Serial transfer of blood from SHIV-89.6-infected monkeys to naive monkeys generated a virus, SHIV-89.6P, that exhibited only modest increases in replication in infected monkeys compared with SHIV-89.6. ${ }^{171}$ However, SHIV-89.6P caused rapid loss of $\mathrm{CD}^{+}{ }^{+} \mathrm{T}$ lymphocytes and, subsequently, AIDSlike illness in inoculated monkeys. The risk of developing AIDS-related disease in monkeys infected with SHIV-89.6P variants is strongly influenced by the degree of decline in $\mathrm{CD}^{+} \mathrm{T}$ lymphocytes during the acute phase of infection. ${ }^{172,173}$ Interestingly, infection of macaques with a pathogenic CCR5-specific enveloped virus (SHIV SF162P) compared with infection with a pathogenic CXCR4-specific enveloped

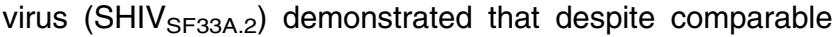
levels of viral replication, animals have distinct pathogenic outcomes. R5-tropic SHIV causes a dramatic loss of CD4 ${ }^{+}$ intestinal $\mathrm{T}$ cells and a gradual depletion in peripheral $\mathrm{CD} 4^{+} \mathrm{T}$ cells, while infection with X4-tropic SHIV causes a profound loss in peripheral $T$ cells that was not paralleled in the intestine. ${ }^{174}$ Altogether, these reports suggest that the capacity to induce T-cell depletion in monkeys is a feature that depends at least in part on the genetic makeup of the envelope protein (X4 versus R5).

The fact that in natural host species, such as SMs and AGMs, SIV infection is nonpathogenic despite high viral loads and CCR5 usage raises an apparent paradox. Indeed, HIV-1, HIV-2, and both pathogenic and nonpathogenic SIVs use CCR5 in association with the CD4 molecule. ${ }^{175-177}$ Moreover, $\mathrm{CD} 4^{+} \mathrm{T}$ cells expressing CCR5 decreases at the peak of viral replication in both pathogenic and nonpathogenic SIV-infected monkeys. ${ }^{166,178-180}$ Altogether, these observations may indicate that depletion of $\mathrm{CCR} 5{ }^{+} \mathrm{CD} 4{ }^{+} \mathrm{T}$ cells is an important event but likely is not the only factor involved in AIDS pathogenesis. These observations also raise questions about the role of alternative chemokine receptors in the immunopathogenesis of AIDS. HIV uses CXCR4 as an alternative coreceptor, whereas SIVs use several chemokine orphan receptors such as BOB/GPR15 and Bonzo/STRL33/CXCR6 for efficient infection and replication in vitro. ${ }^{181-183}$ Several lines of evidence indicated that in vitro BOB/GPR15 is an important SIV coreceptor ${ }^{184-186}$ exhibiting greater activity than CCR5 ${ }^{184}$ Several reports have found that nonpathogenic SIV strains such as SIVagm, SIVsun, SIVIhoest, and SIVrcm use Bonzo/ STRL33/CXCR6 in vitro but less BOB/GPR15. ${ }^{187-189}$ In contrast, pathogenic SIV strains (SIVmne, SIVmac) have been reported to use in vitro both CCR5 and BOB/GPR15 but not Bonzo/STLR33/CXCR6. ${ }^{184-186}$ However, the in vivo role of BOB/GPR15 and Bonzo/STRL33/CXCR6 upon SIV infection is unknown and merit to be further explored.

Thus, studies in NHPs represent key approaches in deciphering the mechanisms leading to CD4 T-cell apoptosis which in turn favors further progression to AIDS.

\section{Acknowledgements}

This work was funded by grants from the Agence Nationale de Recherche sur le Sida (ANRS) to JE and MMT, and by NIH Grants R01-AI52775 and R21-Al54234 to GS. FP was supported by a postdoctoral fellowship from Ensemble Contre le Sida (ECS) and DA was supported by a postdoctoral fellowship from Fondation recherche Médicale (FRM). 


\section{References}

1. Hahn BH, Shaw GM, De Cock KM and Sharp PM (2000) AIDS as a zoonosis: scientific and public health implications. Science 287: 607-614

2. Ho DD, Neumann AU, Perelson AS, Chen W, Leonard JM and Markowitz M (1995) Rapid turnover of plasma virions and CD4 lymphocytes in HIV-1 infection [see comments]. Nature 373: 123-126

3. Grossman Z, Meier-Schellersheim M, Sousa AE, Victorino RM and Paul WE (2002) CD4+ T-cell depletion in HIV infection: are we closer to understanding the cause? Nat. Med. 8: 319-323

4. Douek DC, Picker LJ and Koup RA (2003) T cell dynamics in HIV-1 infection. Annu. Rev. Immunol. 21: 265-304

5. Silvestri $G$ and Feinberg MB (2003) Turnover of lymphocytes and conceptual paradigms in HIV infection. J. Clin. Invest. 112: 821-824

6. Clerici M, Stocks NI, Zajac RA, Boswell RN, Lucey DR, Via CS and Shearer GM (1989) Detection of three distinct patterns of T helper cell dysfunction in asymptomatic, human immunodeficiency virus-seropositive patients Independence of $\mathrm{CD} 4+$ cell numbers and clinical staging. J. Clin. Invest. 84: 1892-1899

7. Courgnaud V, Pourrut X, Bibollet-Ruche F, Mpoudi-Ngole E, Bourgeois A, Delaporte $E$ and Peeters $M$ (2001) Characterization of a novel simian immunodeficiency virus from guereza colobus monkeys (Colobus guereza) in Cameroon: a new lineage in the nonhuman primate lentivirus family. J. Virol. 75: 857-866

8. Sharp PM, Bailes E, Robertson DL, Gao F and Hahn BH (1999) Origins and evolution of AIDS viruses. Biol. Bull. 196: 338-342

9. Peeters M, Honore C, Huet T, Bedjabaga L, Ossari S, Bussi P, Cooper RW and Delaporte $E(1989)$ Isolation and partial characterization of an HIV-related virus occurring naturally in chimpanzees in Gabon. AIDS 3: 625-630

10. Peeters M, Fransen K, Delaporte E, Van den Haesevelde M, Gershy-Damet GM, Kestens L, van der Groen G and Piot P (1992) Isolation and characterization of a new chimpanzee lentivirus (simian immunodeficiency virus isolate cpz-ant) from a wild-captured chimpanzee. AIDS 6: 447-451

11. Gao F, Bailes E, Robertson DL, Chen Y, Rodenburg CM, Michael SF, Cummins LB, Arthur LO, Peeters M, Shaw GM, Sharp PM and Hahn BH (1999) Origin of HIV-1 in the chimpanzee Pan troglodytes troglodytes. Nature 397: $436-441$

12. Chen Z, Luckay A, Sodora DL, Telfer P, Reed P, Gettie A, Kanu JM, Sadek RF, Yee J, Ho DD, Zhang L and Marx PA (1997) Human immunodeficiency virus type 2 (HIV-2) seroprevalence and characterization of a distinct HIV-2 genetic subtype from the natural range of simian immunodeficiency virusinfected sooty mangabeys. J. Virol. 71: 3953-3960

13. Corbet S, Muller-Trutwin MC, Versmisse P, Delarue S, Ayouba A, Lewis J, Brunak S, Martin P, Brun-Vezinet F, Simon F, Barre-Sinoussi $F$ and Mauclere $P$ (2000) env sequences of simian immunodeficiency viruses from chimpanzees in Cameroon are strongly related to those of human immunodeficiency virus group $\mathrm{N}$ from the same geographic area. J. Virol. 74: 529-534

14. Beer BE, Bailes E, Goeken R, Dapolito G, Coulibaly C, Norley SG, Kurth R, Gautier JP, Gautier-Hion A, Vallet D, Sharp PM and Hirsch VM (1999) Simian immunodeficiency virus (SIV) from sun-tailed monkeys (Cercopithecus solatus): evidence for host-dependent evolution of SIV within the C.Ihoest superspecies. J. Virol. 73: 7734-7744

15. Emau $P, M c C l u r e ~ H M$, Isahakia M, Else JG and Fultz PN (1991) Isolation from African Sykes' monkeys (Cercopithecus mitis) of a lentivirus related to human and simian immunodeficiency viruses. J. Virol. 65: 2135-2140

16. Hirsch VM, Dapolito GA, Goldstein S, McClure H, Emau P, Fultz PN, Isahakia M, Lenroot R, Myers $G$ and Johnson PR (1993) A distinct African lentivirus from Sykes' monkeys. J. Virol. 67: 1517-1528

17. Muller MC, Saksena NK, Nerrienet E, Chappey C, Herve VM, Durand JP, Legal-Campodonico P, Lang MC, Digoutte JP and Georges AJ (1993) Simian immunodeficiency viruses from central and western Africa: evidence for a new species-specific lentivirus in tantalus monkeys. J. Virol. 67: 1227-1235

18. Tsujimoto H, Hasegawa A, Maki N, Fukasawa M, Miura T, Speidel S, Cooper RW, Moriyama EN, Gojobori T and Hayami M (1989) Sequence of a novel simian immunodeficiency virus from a wild-caught African mandrill. Nature 341: 539-541

19. Bibollet-Ruche F, Bailes E, Gao F, Pourrut X, Barlow KL, Clewley JP, Mwenda JM, Langat DK, Chege GK, McClure HM, Mpoudi-Ngole E, Delaporte E,
Peeters M, Shaw GM, Sharp PM and Hahn BH (2004) New simian immunodeficiency virus infecting De Brazza's monkeys (Cercopithecus neglectus): evidence for a cercopithecus monkey virus clade. J. Virol. 78: 7748-7762

20. Courgnaud V, Abela B, Pourrut X, Mpoudi-Ngole E, Loul S, Delaporte E and Peeters M (2003) Identification of a new simian immunodeficiency virus lineage with a vpu gene present among different cercopithecus monkeys $(C$. mona, C. cephus, and C. nictitans) from Cameroon. J. Virol. 77: 12523-12534

21. Courgnaud V, Formenty P, Akoua-Koffi C, Noe R, Boesch C, Delaporte E and Peeters M (2003) Partial molecular characterization of two simian immunodeficiency viruses (SIV) from African colobids: SIVwrc from Western red colobus (Piliocolobus badius) and SIVolc from olive colobus (Procolobus verus). J. Virol. 77: 744-748

22. Allan JS, Short M, Taylor ME, Su S, Hirsch VM, Johnson PR, Shaw GM and Hahn BH (1991) Species-specific diversity among simian immunodeficiency viruses from African green monkeys. J. Virol. 65: 2816-2828

23. Clewley JP, Lewis JC, Brown DW and Gadsby EL (1998) A novel simian immunodeficiency virus (SIVdrl) pol sequence from the drill monkey, Mandrillus leucophaeus. J. Virol. 72: 10305-10309

24. Georges-Courbot MC, Lu CY, Makuwa M, Telfer P, Onanga R, Dubreuil G, Chen Z, Smith SM, Georges A, Gao F, Hahn BH and Marx PA (1998) Natural infection of a household pet red-capped mangabey (Cercocebus torquatus torquatus) with a new simian immunodeficiency virus. J. Virol. 72: $600-608$

25. Jin MJ, Hui H, Robertson DL, Muller MC, Barre-Sinoussi F, Hirsch VM, Allan JS, Shaw GM, Sharp PM and Hahn BH (1994) Mosaic genome structure of simian immunodeficiency virus from west African green monkeys. EMBO J. 13: $2935-2947$

26. Souquiere S, Bibollet-Ruche F, Robertson DL, Makuwa M, Apetrei C, Onanga R, Kornfeld C, Plantier JC, Gao F, Abernethy K, White LJ, Karesh W, Telfer P, Wickings EJ, Mauclere P, Marx PA, Barre-Sinoussi F, Hahn BH, MullerTrutwin MC and Simon F (2001) Wild Mandrillus sphinx are carriers of two types of lentivirus. J. Virol. 75: 7086-7096

27. Silvestri G, Sodora DL, Koup RA, Paiardini M, O'Neil SP, McClure HM, Staprans SI and Feinberg MB (2003) Nonpathogenic SIV infection of sooty mangabeys is characterized by limited bystander immunopathology despite chronic high-level viremia. Immunity 18: 441-452

28. Rey-Cuille MA, Berthier JL, Bomsel-Demontoy MC, Chaduc Y, Montagnier L, Hovanessian AG and Chakrabarti LA (1998) Simian immunodeficiency virus replicates to high levels in sooty mangabeys without inducing disease. J. Virol. 72: 3872-3886

29. Broussard SR, Staprans SI, White R, Whitehead EM, Feinberg MB and Allan JS (2001) Simian immunodeficiency virus replicates to high levels in naturally infected African green monkeys without inducing immunologic or neurologic disease. J. Virol. 75: 2262-2275

30. Chakrabarti LA, Lewin SR, Zhang L, Gettie A, Luckay A, Martin LN, Skulsky E, Ho DD, Cheng-Mayer $C$ and Marx PA (2000) Normal T-cell turnover in sooty mangabeys harboring active simian immunodeficiency virus infection. J. Virol. 74: $1209-1223$

31. Diop OM, Gueye A, Dias-Tavares M, Kornfeld C, Faye A, Ave P, Huerre M, Corbet S, Barre-Sinoussi F and Muller-Trutwin MC (2000) High levels of viral replication during primary simian immunodeficiency virus SIVagm infection are rapidly and strongly controlled in African green monkeys. J. Virol. 74: 7538-7547

32. Onanga R, Kornfeld C, Pandrea I, Estaquier J, Souquiere S, Rouquet $P$, Mavoungou VP, Bourry O, M'Boup S, Barre-Sinoussi F, Simon F, Apetrei C, Roques $P$ and Muller-Trutwin MC (2002) High levels of viral replication contrast with only transient changes in $\mathrm{CD} 4(+)$ and $\mathrm{CD} 8(+)$ cell numbers during the early phase of experimental infection with simian immunodeficiency virus SIVmnd-1 in Mandrillus sphinx. J. Virol. 76: 10256-10263

33. Ling B, Apetrei C, Pandrea I, Veazey RS, Lackner AA, Gormus B and Marx PA (2004) Classic AIDS in a sooty mangabey after an 18-year natural infection. J. Virol. 78: 8902-8908

34. Pandrea I, Onanga R, Kornfeld C, Rouquet P, Bourry O, Clifford S, Telfer PT, Abernethy K, White LT, Ngari P, Muller-Trutwin M, Roques P, Marx PA, Simon F and Apetrei C (2003) High levels of SIVmnd-1 replication in chronically infected Mandrillus sphinx. Virology 317: 119-127

35. Goldstein S, Ourmanov I, Brown CR, Beer BE, Elkins WR, Plishka R, BucklerWhite $A$ and Hirsch VM (2000) Wide range of viral load in healthy African 
green monkeys naturally infected with simian immunodeficiency virus. J. Virol. 74: $11744-11753$

36. Gueye A, Diop OM, Ploquin MJ, Kornfeld C, Faye A, Cumont MC, Hurtrel B, Barre-Sinoussi F and Muller-Trutwin MC (2004) Viral load in tissues during the early and chronic phase of non-pathogenic SIVagm infection. J. Med. Primatol. 33: 83-97

37. Beer B, Scherer J, zur Megede J, Norley S, Baier M and Kurth R (1996) Lack of dichotomy between virus load of peripheral blood and lymph nodes during long-term simian immunodeficiency virus infection of African green monkeys. Virology 219: 367-375

38. Johnson PR, Goldstein S, London WT, Fomsgaard A and Hirsch VM (1990) Molecular clones of SIVsm and SIVagm: experimental infection of macaques and African green monkeys. J. Med. Primatol. 19: 279-286

39. Hirsch VM, Dapolito G, Johnson PR, Elkins WR, London WT, Montali RJ, Goldstein S and Brown C (1995) Induction of AIDS by simian immunodeficiency virus from an African green monkey: species-specific variation in pathogenicity correlates with the extent of in vivo replication. J. Virol. 69: 955-967

40. Hirsch VM, Campbell BJ, Bailes E, Goeken R, Brown C, Elkins WR, Axthelm M, Murphey-Corb M and Sharp PM (1999) Characterization of a novel simian immunodeficiency virus (SIV) from L'Hoest monkeys (Cercopithecus l'hoesti): implications for the origins of SIVmnd and other primate lentiviruses. J. Virol. 73: $1036-1045$

41. Ameisen JC, Estaquier J and Idziorek T (1994) From AIDS to parasite infection: pathogen-mediated subversion of programmed cell death as a mechanism for immune dysregulation. Immunol. Rev. 142: 9-51

42. Meyaard L, Otto SA, Jonker RR, Mijnster MJ, Keet RP and Miedema F (1992) Programmed death of T cells in HIV-1 infection. Science 257: 217-219

43. Sarin A, Clerici M, Blatt SP, Hendrix CW, Shearer GM and Henkart PA (1994) Inhibition of activation-induced programmed cell death and restoration of defective immune responses of HIV + donors by cysteine protease inhibitors. J. Immunol. 153: 862-872

44. Gougeon ML, Garcia S, Heeney J, Tschopp R, Lecoeur H, Guetard D, Rame V, Dauguet $C$ and Montagnier L (1993) Programmed cell death in AIDSrelated HIV and SIV infections. AIDS Res. Hum. Retroviruses 9: 553-563

45. Oyaizu N, McCloskey TW, Coronesi M, Chirmule N, Kalyanaraman VS and Pahwa S (1993) Accelerated apoptosis in peripheral blood mononuclear cells (PBMCs) from human immunodeficiency virus type-1 infected patients and in CD4 cross-linked PBMCs from normal individuals. Blood 82: 3392-3400

46. Clerici M, Sarin A, Coffman RL, Wynn TA, Blatt SP, Hendrix CW, Wolf SF, Shearer GM and Henkart PA (1994) Type 1/type 2 cytokine modulation of Tcell programmed cell death as a model for human immunodeficiency virus pathogenesis. Proc. Natl. Acad. Sci. USA 91: 11811-11815

47. Lewis DE, Tang DS, Adu-Oppong A, Schober W and Rodgers JR (1994) Anergy and apoptosis in CD8+ T cells from HIV-infected persons. J. Immunol. 153: 412-420

48. Estaquier J, Idziorek T, Zou W, Emilie D, Farber CM, Bourez JM and Ameisen JC (1995) $T$ helper type $1 / T$ helper type 2 cytokines and $T$ cell death: preventive effect of interleukin 12 on activation-induced and CD95 (FAS/APO1)-mediated apoptosis of CD4+ T cells from human immunodeficiency virusinfected persons. J. Exp. Med. 182: 1759-1767

49. Estaquier J, Tanaka M, Suda T, Nagata S, Golstein P and Ameisen JC (1996) Fas-mediated apoptosis of $\mathrm{CD} 4+$ and $\mathrm{CD} 8+\mathrm{T}$ cells from human immunodeficiency virus-infected persons: differential in vitro preventive effect of cytokines and protease antagonists. Blood 87: 4959-4966

50. Katsikis PD, Wunderlich ES, Smith CA and Herzenberg LA (1995) Fas antigen stimulation induces marked apoptosis of $T$ lymphocytes in human immunodeficiency virus-infected individuals. J. Exp. Med. 181: 2029-2036

51. Estaquier J, Monceaux V, Cumont MC, Aubertin AM, Hurtrel B and Ameisen JC (2000) Early changes in peripheral blood T cells during primary infection of rhesus macaques with a pathogenic SIV. J. Med. Primatol. 29: 127-135

52. Muro-Cacho CA, Pantaleo G and Fauci AS (1995) Analysis of apoptosis in lymph nodes of HIV-infected persons. Intensity of apoptosis correlates with the general state of activation of the lymphoid tissue and not with stage of disease or viral burden. J. Immunol. 154: 5555-5566

53. Finkel TH, Tudor-Williams G, Banda NK, Cotton MF, Curiel T, Monks C, Baba TW, Ruprecht RM and Kupfer A (1995) Apoptosis occurs predominantly in bystander cells and not in productively infected cells of HIV- and SIV-infected lymph nodes [see comments]. Nat. Med. 1: 129-134
54. Marlink R, Kanki P, Thior I, Travers K, Eisen G, Siby T, Traoré I, Hsieh CC, Dia MC, Gueye EH, Hellinger J, Gueye-Ndiaye A, Sankalé J-L, Ndoye I, Mboup S and Essex M (1994) Reduced rate of disease development after HIV-2 infection as compared to HIV-1. Science 265: 1587-1590

55. Michel P, Balde AT, Roussilhon C, Aribot G, Sarthou JL and Gougeon ML (2000) Reduced immune activation and $T$ cell apoptosis in human immunodeficiency virus type 2 compared with type 1: correlation of T cell apoptosis with beta2 microglobulin concentration and disease evolution. J. Infect. Dis. 181: $64-75$

56. Prati E, Gorla R, Malacarne F, Airo P, Brugnoni D, Gargiulo F, Tebaldi A, Castelli F, Carosi $G$ and Cattaneo R (1997) Study of spontaneous apoptosis in HIV+ patients: correlation with clinical progression and T cell loss. AIDS Res. Hum. Retroviruses 13: 1501-1508

57. Liegler TJ, Yonemoto W, Elbeik T, Vittinghoff E, Buchbinder SP and Greene WC (1998) Diminished spontaneous apoptosis in lymphocytes from human immunodeficiency virus-infected long-term nonprogressors. J. Infect. Dis. 178: 669-679

58. Chavan SJ, Tamma SL, Kaplan M, Gersten M and Pahwa SG (1999) Reduction in $\mathrm{T}$ cell apoptosis in patients with HIV disease following antiretroviral therapy. Clin. Immunol. 93: 24-33

59. Aries SP, Weyrich K, Schaaf B, Hansen F, Dennin RH and Dalhoff K (1998) Early T-cell apoptosis and Fas expression during antiretroviral therapy in individuals infected with human immunodeficiency virus-1. Scand. J. Immunol. 48: 86-91

60. Badley AD, Dockrell DH, Algeciras A, Ziesmer S, Landay A, Lederman MM, Connick E, Kessler H, Kuritzkes D, Lynch DH, Roche P, Yagita $\mathrm{H}$ and Paya CV (1998) In vivo analysis of Fas/FasL interactions in HIV-infected patients. J. Clin. Invest. 102: 79-87

61. Bohler T, Walcher J, Holzl-Wenig G, Geiss M, Buchholz B, Linde R and Debatin KM (1999) Early effects of antiretroviral combination therapy on activation, apoptosis and regeneration of T cells in HIV-1-infected children and adolescents. AIDS 13: 779-789

62. Hansjee N, Kaufmann GR, Strub C, Weber R, Battegay M, Erb P and the Swiss HIV Cohort Study (2004) Persistent apoptosis in HIV-1-infected individuals receiving potent antiretroviral therapy is associated with poor recovery of CD4 T lymphocytes. J. Acquir. Immune. Defic. Syndr. 36: 671677

63. Pitrak DL, Bolanos J, Hershow R and Novak RM (2001) Discordant CD4 T lymphocyte responses to antiretroviral therapy for HIV infection are associated with ex-vivo rates of apoptosis. AIDS 15: 1317-1319

64. Badley AD, Pilon AA, Landay A and Lynch DH (2000) Mechanisms of HIVassociated lymphocyte apoptosis. Blood 96: 2951-2964

65. Little SJ, McLean AR, Spina CA, Richman DD and Havlir DV (1999) Viral dynamics of acute HIV-1 infection. J. Exp. Med. 190: 841-850

66. Soudeyns H and Pantaleo G (1999) The moving target: mechanisms of HIV persistence during primary infection. Immunol. Today 20: 446-450

67. D'Souza MP and Mathieson BJ (1996) Early phases of HIV type 1 infection. AIDS Res. Hum. Retroviruses 12: 1-9

68. Reimann KA, Tenner-Racz K, Racz P, Montefiori DC, Yasutomi Y, Lin W, Ransil BJ and Letvin NL (1994) Immunopathogenic events in acute infection of rhesus monkeys with simian immunodeficiency virus of macaques. J. Virol. 68: $2362-2370$

69. Chakrabarti L, Cumont MC, Montagnier L and Hurtrel B (1994) Variable course of primary simian immunodeficiency virus infection in lymph nodes: relation to disease progression. J. Virol. 68: 6634-6643

70. Mellors JW, Kingsley LA, Rinaldo Jr. CR, Todd JA, Hoo BS, Kokka RP and Gupta P (1995) Quantitation of HIV-1 RNA in plasma predicts outcome after seroconversion. Ann. Intern. Med. 122: 573-579

71. Watson A, Ranchalis J, Travis B, McClure J, Sutton W, Johnson PR, Hu SL and Haigwood NL (1997) Plasma viremia in macaques infected with simian immunodeficiency virus: plasma viral load early in infection predicts survival. J. Virol. 71: 284-290

72. Lifson JD, Nowak MA, Goldstein S, Rossio JL, Kinter A, Vasquez G, Wiltrout TA, Brown C, Schneider D, Wahl L, Lloyd AL, Williams J, Elkins WR, Fauci AS and Hirsch VM (1997) The extent of early viral replication is a critical determinant of the natural history of simian immunodeficiency virus infection. J. Virol. 71: 9508-9514

73. Staprans SI, Dailey PJ, Rosenthal A, Horton C, Grant RM, Lerche N and Feinberg MB (1999) Simian immunodeficiency virus disease course is 
predicted by the extent of virus replication during primary infection. J. Virol. 73 : 4829-4839

74. Monceaux V, Estaquier J, Fevrier M, Cumont MC, Riviere Y, Aubertin AM, Ameisen JC and Hurtrel B (2003) Extensive apoptosis in lymphoid organs during primary SIV infection predicts rapid progression towards AIDS. AIDS 17: $1585-1596$

75. lida T, Ichimura H, Ui M, Shimada T, Akahata W, Igarashi T, Kuwata T, Ido E, Yonehara S, Imanishi J and Hayami M (1999) Sequential analysis of apoptosis induction in peripheral blood mononuclear cells and lymph nodes in the early phase of pathogenic and nonpathogenic SIVmac infection. AIDS Res. Hum. Retroviruses 15: 721-729

76. Wykrzykowska JJ, Rosenzweig M, Veazey RS, Simon MA, Halvorsen K, Desrosiers RC, Johnson RP and Lackner AA (1998) Early regeneration of thymic progenitors in rhesus macaques infected with simian immunodeficiency virus. J. Exp. Med. 187: 1767-1778

77. Sodora DL, Milush JM, Ware F, Wozniakowski A, Montgomery L, McClure HM, Lackner AA, Marthas M, Hirsch V, Johnson RP, Douek DC and Koup RA (2002) Decreased levels of recent thymic emigrants in peripheral blood of simian immunodeficiency virus-infected macaques correlate with alterations within the thymus. J. Virol. 76: 9981-9990

78. Davis IC, Girard M and Fultz PN (1998) Loss of CD4+ T cells in human immunodeficiency virus type 1-infected chimpanzees is associated with increased lymphocyte apoptosis. J. Virol. 72: 4623-4632

79. del Llano AM, Amieiro-Puig JP, Kraiselburd EN, Kessler MJ, Malaga CA and Lavergne JA (1993) The combined assessment of cellular apoptosis, mitochondrial function and proliferative response to pokeweed mitogen has prognostic value in SIV infection. J. Med. Primatol. 22: 147-153

80. Estaquier J, Idziorek T, De Bels F, Barre-Sinoussi F, Hurtrel B, Aubertin AM, Venet A, Mehtali M, Muchmore E, Michel P, Mouton Y, Girard M and Ameisen JC (1994) Programmed cell death and AIDS: significance of T-cell apoptosis in pathogenic and nonpathogenic primate lentiviral infections. Proc. Natl. Acad. Sci. USA 91: 9431-9435

81. Schuitemaker H, Meyaard L, Kootstra NA, Dubbes R, Otto SA, Tersmette M, Heeney JL and Miedema F (1993) Lack of T cell dysfunction and programmed cell death in human immunodeficiency virus type 1-infected chimpanzees correlates with absence of monocytotropic variants. J. Infect. Dis. 168: 1140-1147

82. Reinberger S, Spring M, Nisslein T, Stahl-Hennig C, Hunsmann G and Dittmer $\mathrm{U}$ (1999) Kinetics of lymphocyte apoptosis in macaques infected with different simian immunodeficiency viruses or simian/human immunodeficiency hybrid viruses. Clin. Immunol. 90: 141-146

83. Dittmer U, Petry H, Stahl-Hennig C, Nisslein T, Spring M, Luke W, Bodemer W, Kaup FJ and Hunsmann G (1996) T cell apoptosis in human immunodeficiency virus type 2- and simian immunodeficiency virus-infected macaques. J. Gen. Virol. 77: 2433-2436

84. Villinger F, Folks TM, Lauro S, Powell JD, Sundstrom JB, Mayne A and Ansari AA (1996) Immunological and virological studies of natural SIV infection of disease-resistant nonhuman primates. Immunol. Lett. 51: 59-68

85. Novembre FJ, de Rosayro J, Nidtha S, O'Neil SP, Gibson TR, EvansStrickfaden T, Hart CE and McClure HM (2001) Rapid CD4(+) T-cell loss induced by human immunodeficiency virus type $1(\mathrm{NC})$ in uninfected and previously infected chimpanzees. J. Virol. 75: 1533-1539

86. Aries SP, Schaaf B, Muller C, Dennin RH and Dalhoff K (1995) Fas (CD95) expression on $\mathrm{CD} 4+\mathrm{T}$ cells from HIV-infected patients increases with disease progression. J. Mol. Med. 73: 591-593

87. Baumler CB, Bohler T, Herr I, Benner A, Krammer PH and Debatin KM (1996) Activation of the CD95 (APO-1/Fas) system in T cells from human immunodeficiency virus type-1-infected children. Blood 88: 1741-1746

88. Bohler T, Debatin KM and Linde R (1999) Sensitivity of CD4+ peripheral blood $T$ cells toward spontaneous and CD95 (APO-1/Fas)-induced apoptosis in pediatric human immunodeficiency virus infection [letter; comment]. Blood 94: 1829-1833

89. Dockrell DH, Badley AD, Algeciras-Schimnich A, Simpson M, Schut R, Lynch DH and Paya CV (1999) Activation-induced CD4+ T cell death in HIV-positive individuals correlates with Fas susceptibility, CD4+ T cell count, and HIV plasma viral copy number. AIDS Res. Hum. Retroviruses 15: 1509-1518

90. Gehri R, Hahn S, Rothen M, Steuerwald M, Nuesch R and Erb P (1996) The Fas receptor in HIV infection: expression on peripheral blood lymphocytes and role in the depletion of T cells. AIDS 10: 9-16
91. Hosaka N, Oyaizu N, Kaplan MH, Yagita H and Pahwa S (1998) Membrane and soluble forms of Fas (CD95) and Fas ligand in peripheral blood mononuclear cells and in plasma from human immunodeficiency virusinfected persons. J. Infect. Dis. 178: 1030-1039

92. McCloskey TW, Oyaizu N, Kaplan M and Pahwa S (1995) Expression of the Fas antigen in patients infected with human immunodeficiency virus. Cytometry 22: 111-114

93. Silvestris F, Cafforio P, Frassanito MA, Tucci M, Romito A, Nagata S and Dammacco $F$ (1996) Overexpression of Fas antigen on T cells in advanced HIV-1 infection: differential ligation constantly induces apoptosis. AIDS 10: $131-141$

94. Sloand EM, Young NS, Kumar P, Weichold FF, Sato T and Maciejewski JP (1997) Role of Fas ligand and receptor in the mechanism of T-cell depletion in acquired immunodeficiency syndrome: effect on $\mathrm{CD} 4+$ lymphocyte depletion and human immunodeficiency virus replication. Blood 89: 1357-1363

95. Algeciras A, Dockrell DH, Lynch DH and Paya CV (1998) CD4 regulates susceptibility to Fas ligand- and tumor necrosis factor-mediated apoptosis. J. Exp. Med. 187: 711-720

96. Badley AD, Dockrell D, Simpson M, Schut R, Lynch DH, Leibson P and Paya CV (1997) Macrophage-dependent apoptosis of CD4+ T lymphocytes from HIV-infected individuals is mediated by FasL and tumor necrosis factor. J. Exp. Med. 185: 55-64

97. Jeremias I, Herr I, Boehler T and Debatin KM (1998) TRAIL/Apo-2-ligandinduced apoptosis in human T cells. Eur. J. Immunol. 28: 143-152

98. Katsikis PD, Garcia-Ojeda ME, Torres-Roca JF, Tijoe IM, Smith CA and Herzenberg LA (1997) Interleukin-1 beta converting enzyme-like protease involvement in Fas-induced and activation-induced peripheral blood T cell apoptosis in HIV infection. TNF-related apoptosis-inducing ligand can mediate activation-induced T cell death in HIV infection. J. Exp. Med. 186: 1365-1372

99. de Oliveira Pinto LM, Garcia S, Lecoeur H, Rapp C and Gougeon ML (2002) Increased sensitivity of $T$ lymphocytes to tumor necrosis factor receptor 1 (TNFR1)- and TNFR2-mediated apoptosis in HIV infection: relation to expression of Bcl-2 and active caspase-8 and caspase-3. Blood 99: 1666-1675

100. Herbein G, Mahlknecht U, Batliwalla F, Gregersen P, Pappas T, Butler J, O'Brien WA and Verdin E (1998) Apoptosis of CD8+ T cells is mediated by macrophages through interaction of HIV gp120 with chemokine receptor CXCR4. Nature 395: 189-194

101. Arnoult D, Petit F, Lelievie JD, Lecossier D, Hance A, Monceaux V, Ho Tsong Fang R, Huntrel B, Ameisen JC and Estaquier J (2003) Caspase-dependent and -independent $\mathrm{T}$-cell death pathways in pathogenic simian immunodeficiency virus infection: relationship to disease progression. Cell Death Differ. 10: 1240-1252

102. Mueller YM, De Rosa SC, Hutton JA, Witek J, Roederer M, Altman JD and Katsikis PD (2001) Increased CD95/Fas-induced apoptosis of HIV-specific CD8(+) T cells. Immunity 15: 871-882

103. Hengartner $\mathrm{MO}(2000)$ The biochemistry of apoptosis. Nature 407: 770-776

104. Holler N, Zaru R, Micheau O, Thome M, Attinger A, Valitutti S, Bodmer J-L, Schneider P, Seed B and Tschopp J (2000) Fas triggers an alternative, caspase-8-independent cell death pathway using the kinase RIP as effector molecule. Nat Immunol 1: 489-495

105. Badley AD, Parato K, Cameron DW, Kravcik S, Phenix BN, Ashby D, Kumar A, Lynch DH, Tschopp J and Angel JB (1999) Dynamic correlation of apoptosis and immune activation during treatment of HIV infection. Cell Death Differ. 6: 420-432

106. Rathmell JC, Vander Heiden MG, Harris MH, Frauwirth KA and Thompson CB (2000) In the absence of extrinsic signals, nutrient utilization by lymphocytes is insufficient to maintain either cell size or viability. Mol. Cell 6: 683-692

107. Castedo M, Macho A, Zamzami N, Hirsch T, Marchetti $P$, Uriel J and Kroemer G (1995) Mitochondrial perturbations define lymphocytes undergoing apoptotic depletion in vivo. Eur. J. Immunol. 25: 3277-3284

108. Bouillet P, Metcalf D, Huang DC, Tarlinton DM, Kay TW, Kontgen F, Adams JM and Strasser A (1999) Proapoptotic Bcl-2 relative Bim required for certain apoptotic responses, leukocyte homeostasis, and to preclude autoimmunity. Science 286: 1735-1738

109. Bouillet P, Purton JF, Godfrey DI, Zhang LC, Coultas L, Puthalakath H, Pellegrini M, Cory S, Adams JM and Strasser A (2002) BH3-only Bcl-2 family member Bim is required for apoptosis of autoreactive thymocytes. Nature 415 : 922-926 
110. Bouillet $P$, Cory S, Zhang LC, Strasser A and Adams JM (2001) Degenerative disorders caused by $\mathrm{BCl}-2$ deficiency prevented by loss of its $\mathrm{BH} 3-$ only antagonist Bim. Dev. Cell 1: 645-653

111. Wei MC, Zong WX, Cheng EH, Lindsten T, Panoutsakopoulou V, Ross AJ, Roth KA, MacGregor GR, Thompson CB and Korsmeyer SJ (2001) Proapoptotic BAX and BAK: a requisite gateway to mitochondrial dysfunction and death. Science 292: 727-730

112. Ranger AM, Malynn BA and Korsmeyer SJ (2001) Mouse models of cell death. Nat. Genet. 28: 113-118

113. Lindsten T, Ross AJ, King A, Zong WX, Rathmell JC, Shiels HA, Ulrich $E$, Waymire KG, Mahar P, Frauwirth K, Chen Y, Wei M, Eng VM, Adelman DM, Simon MC, Ma A, Golden JA, Evan G, Korsmeyer SJ, MacGregor GR and Thompson CB (2000) The combined functions of proapoptotic Bcl-2 family members bak and bax are essential for normal development of multiple tissues. Mol. Cell 6: 1389-1399

114. Gross A, Jockel J, Wei MC and Korsmeyer SJ (1998) Enforced dimerization of BAX results in its translocation, mitochondrial dysfunction and apoptosis. EMBO J. 17: 3878-3885

115. Desagher S, Osen-Sand A, Nichols A, Eskes R, Montessuit S, Lauper S, Maundrell K, Antonsson B and Martinou JC (1999) Bid-induced conformational change of Bax is responsible for mitochondrial cytochrome $\mathrm{C}$ release during apoptosis. J. Cell Biol. 144: 891-901

116. Mueller YM, Bojczuk PM, Halstead ES, Kim AH, Witek J, Altman JD and Katsikis PD (2003) IL-15 enhances survival and function of HIV-specific CD8+ T cells. Blood 101: 1024-1029

117. Mueller YM, Makar V, Bojczuk PM, Witek J and Katsikis PD (2003) IL-15 enhances the function and inhibits CD95/Fas-induced apoptosis of human CD4+ and CD8+ effector-memory T cells. Int. Immunol. 15: 49-58

118. Naora $H$ and Gougeon M (1999) Activation, survival and apoptosis of CD45RO+ and CD45RO - T cells of human immunodeficiency virus-infected individuals: effects of interleukin-15 and comparison with interleukin-2. Immunology 97: 181-187

119. Chehimi J, Marshall JD, Salvucci O, Frank I, Chehimi S, Kawecki S, Bacheller D, Rifat S and Chouaib S (1997) IL-15 enhances immune functions during HIV infection. J. Immunol. 158: 5978-5987

120. Adachi Y, Oyaizu N, Than S, McCloskey TW and Pahwa S (1996) IL-2 rescues in vitro lymphocyte apoptosis in patients with HIV infection: correlation with its ability to block culture-induced down-modulation of Bcl-2. J. Immunol. 157: 4184-4193

121. Naora H and Gougeon ML (1999) Interleukin-15 is a potent survival factor in the prevention of spontaneous but not CD95-induced apoptosis in CD4 and CD8T lymphocytes of HIV-infected individuals. Correlation with its ability to increase BCL-2 expression. Cell Death Differ. 6: 1002-1011

122. Paiardini M, Galati D, Cervasi B, Cannavo G, Galluzzi L, Montroni M, Guetard $D$, Magnani M, Piedimonte $G$ and Silvestri $G$ (2001) Exogenous interleukin-2 administration corrects the cell cycle perturbation of lymphocytes from human immunodeficiency virus-infected individuals. J. Virol. 75: 10843-10855

123. Piedimonte G, Corsi D, Paiardini M, Cannavo G, lentile R, Picerno I, Montroni M, Silvestri G and Magnani M (1999) Unscheduled cyclin B expression and p34 cdc2 activation in T lymphocytes from HIV-infected patients. AIDS 13: 1159-1164

124. Paiardini M, Cervasi B, Dunham R, Sumpter B, Radziewicz H and Silvestri G (2004) Cell-cycle dysregulation in the immunopathogenesis of AIDS Immunol. Res. 29: 253-268

125. Paiardini M, Cervasi B, Galati D, Dominici S, Albrecht $H$, Sfacteria A, Magnani M, Silvestri G and Piedimonte G (2004) Early correction of cell cycle perturbations predicts the immunological response to therapy in HIV-infected patients. AIDS 18: 393-402

126. Cannavo G, Paiardini M, Galati D, Cervasi B, Montroni M, De Vico G, Guetard D, Bocchino ML, Picerno I, Magnani M, Silvestri G and Piedimonte G (2001) Abnormal intracellular kinetics of cell-cycle-dependent proteins in lymphocytes from patients infected with human immunodeficiency virus: a novel biologic link between immune activation, accelerated T-cell turnover, and high levels of apoptosis. Blood 97: 1756-1764

127. Galati D, Paiardini $M$, Cervasi $B$, Albrecht $H$, Bocchino $M$, Costantini A, Montroni M, Magnani M, Piedimonte G and Silvestri G (2003) Specific changes in the posttranslational regulation of nucleolin in lymphocytes from patients infected with human immunodeficiency virus. J. Infect. Dis. 188 1483-1491
128. Bostik P, Dodd GL, Villinger F, Mayne AE and Ansari AA (2004) Dysregulation of the polo-like kinase pathway in CD4+ T cells is characteristic of pathogenic simian immunodeficiency virus infection. J. Virol. 78: 1464-1472

129. Herbein G, Van Lint C, Lovett JL and Verdin E (1998) Distinct mechanisms trigger apoptosis in human immunodeficiency virus type 1-infected and in uninfected bystander T lymphocytes. J. Virol. 72: 660-670

130. Chirmule N and Pahwa S (1996) Envelope glycoproteins of human immunodeficiency virus type 1: profound influences on immune functions. Microbiol. Rev. 60: 386-406

131. Vlahakis SR, Algeciras-Schimnich A, Bou G, Heppelmann CJ, Villasis-Keever A, Collman RC and Paya CV (2001) Chemokine-receptor activation by env determines the mechanism of death in HIV-infected and uninfected T lymphocytes. J. Clin. Invest. 107: 207-215

132. Wang ZQ, Dudhane A, Orlikowsky T, Clarke K, Li X, Darzynkiewicz Z and Hoffmann MK (1994) CD4 engagement induces Fas antigen-dependent apoptosis of T cells in vivo. Eur. J. Immunol. 24: 1549-1552

133. Desbarats J, Freed JH, Campbell PA and Newell MK (1996) Fas (CD95) expression and death-mediating function are induced by $\mathrm{CD} 4$ cross-linking on CD4+ T cells. Proc. Natl. Acad. Sci. USA 93: 11014-11018

134. Oyaizu N, McCloskey TW, Than S, Hu R, Kalyanaraman VS and Pahwa S (1994) Cross-linking of CD4 molecules upregulates Fas antigen expression in lymphocytes by inducing interferon-gamma and tumor necrosis factor-alpha secretion. Blood 84: 2622-2631

135. Tateyama M, Oyaizu N, McCloskey TW, Than S and Pahwa S (2000) CD4 T lymphocytes are primed to express Fas ligand by CD4 cross-linking and to contribute to CD8 T-cell apoptosis via Fas/FasL death signaling pathway. Blood 96: 195-202

136. Ferri KF, Jacotot E, Blanco J, Este JA, Zamzami N, Susin SA, Xie Z, Brothers G, Reed JC, Penninger JM and Kroemer G (2000) Apoptosis control in syncytia induced by the HIV type 1-envelope glycoprotein complex: role of mitochondria and caspases. J. Exp. Med. 192: 1081-1092

137. Sodroski J, Goh WC, Rosen C, Campbell K and Haseltine WA (1986) Role of the HTLV-III/LAV envelope in syncytium formation and cytopathicity. Nature 322: $470-474$

138. Lifson JD, Reyes GR, McGrath MS, Stein BS and Engleman EG (1986) AIDS retrovirus induced cytopathology: giant cell formation and involvement of $\mathrm{CD}$ antigen. Science 232: 1123-1127

139. McEntee MF, Sharma DP, Zink MC, Adams RJ, Flexner C, Clements JE and Narayan $O$ (1991) Rhesus monkey macrophages infected with simian immunodeficiency virus cause rapid lysis of CD4-bearing lymphocytes. J. Gen. Virol. 72 (Part 2): 317-324

140. Chuang LF, Killam Jr KF and Chuang RY (1993) Increased replication of simian immunodeficiency virus in CEM x174 cells by morphine sulfate. Biochem. Biophys. Res. Commun. 195: 1165-1173

141. Suzuki S, Carlos MP, Chuang LF, Torres JV, Doi RH and Chuang RY (2002) Methadone induces CCR5 and promotes AIDS virus infection. FEBS Lett. 519: 173-177

142. Ryzhova EV, Crino P, Shawver L, Westmoreland SV, Lackner AA and Gonzalez-Scarano F (2002) Simian immunodeficiency virus encephalitis: analysis of envelope sequences from individual brain multinucleated giant cells and tissue samples. Virology 297: $57-67$

143. Xing $H Q$, Moritoyo $T$, Mori $K$, Tadakuma $K$, Sugimoto $C$, Ono $F$, Hayakawa $H$ and Izumo S (2003) Simian immunodeficiency virus encephalitis in the white matter and degeneration of the cerebral cortex occur independently in simian immunodeficiency virus-infected monkey. J. Neurovirol. 9: 508-518

144. Adamson DC, Dawson TM, Zink MC, Clements JE and Dawson VL (1996) Neurovirulent simian immunodeficiency virus infection induces neuronal, endothelial, and glial apoptosis. Mol. Med. 2: 417-428

145. Berndt C, Mopps B, Angermuller S, Gierschik P and Krammer PH (1998) CXCR4 and CD4 mediate a rapid CD95-independent cell death in CD4(+) T cells. Proc. Natl. Acad. Sci. USA 95: 12556-12561

146. Biard-Piechaczyk M, Robert-Hebmann V, Richard V, Roland J, Hipskind RA and Devaux C (2000) Caspase-dependent apoptosis of cells expressing the chemokine receptor CXCR4 is induced by cell membrane-associated human immunodeficiency virus type 1 envelope glycoprotein (gp120). Virology 268 329-344

147. Blanco J, Jacotot E, Cabrera C, Cardona A, Clotet B, De Clercq E and Este JA (1999) The implication of the chemokine receptor CXCR4 in HIV-1 envelope 
protein-induced apoptosis is independent of the $G$ protein-mediated signalling. AIDS 13: 909-917

148. Hesselgesser J, Taub D, Baskar P, Greenberg M, Hoxie J, Kolson DL and Horuk R (1998) Neuronal apoptosis induced by HIV-1 gp120 and the chemokine SDF-1 alpha is mediated by the chemokine receptor CXCR4. Curr. Biol. 8: 595-598

149. Mahlknecht $U$ and Herbein $G$ (2001) Macrophages and T-cell apoptosis in HIV infection: a leading role for accessory cells? Trends Immunol. 22: 256-260

150. Badley AD, McElhinny JA, Leibson PJ, Lynch DH, Alderson MR and Paya CV (1996) Upregulation of Fas ligand expression by human immunodeficiency virus in human macrophages mediates apoptosis of uninfected $T$ lymphocytes. J. Virol. 70: 199-206

151. Herbeuval JP, Boasso A, Grivel JC, Hardy AW, Anderson SA, Dolan MJ, Chougnet C, Lifson JD and Shearer GM (2005) TNF-related apoptosisinducing ligand (TRAIL) in HIV-1-infected patients and its in vitro production by antigen-presenting cells. Blood 105: 2458-2464

152. Lum JJ, Pilon AA, Sanchez-Dardon J, Phenix BN, Kim JE, Mihowich J, Jamison K, Hawley-Foss N, Lynch DH and Badley AD (2001) Induction of cell death in human immunodeficiency virus-infected macrophages and resting memory CD4 T cells by TRAIL/Apo2 I. J. Virol. 75: 11128-11136

153. Dockrell DH, Badley AD, Villacian JS, Heppelmann CJ, Algeciras A, Ziesmer S, Yagita H, Lynch DH, Roche PC, Leibson PJ and Paya CV (1998) The expression of Fas ligand by macrophages and its upregulation by human immunodeficiency virus infection. J. Clin. Invest. 101: 2394-2405

154. Petit F, Corbeil J, Lelievre JD, Parseval LM, Pinon G, Green DR, Ameisen JC and Estaquier J (2001) Role of CD95-activated caspase-1 processing of IL1beta in TCR-mediated proliferation of HIV-infected CD4(+) T cells. Eur. J. Immunol. 31: 3513-3524

155. Estaquier J, Lelievre JD, Petit F, Brunner T, Moutouh-De Parseval L, Richman $\mathrm{DD}$, Ameisen JC and Corbeil $\mathrm{J}$ (2002) Effects of antiretroviral drugs on human immunodeficiency virus type 1-induced CD4(+) T-cell death. J. Virol. 76 5966-5973

156. Dean M, Carrington M, Winkler C, Huttley GA, Smith MW, Allikmets R, Goedert JJ, Buchbinder SP, Vittinghoff E, Gomperts E, Donfield S, Vlahov D, Kaslow R, Saah A, Rinaldo C, Detels R and O'Brien SJ (1996) Genetic restriction of HIV-1 infection and progression to AIDS by a deletion allele of the CKR5 structural gene. Hemophilia Growth and Development Study, Multicenter AIDS Cohort Study, Multicenter Hemophilia Cohort Study, San Francisco City Cohort, ALIVE Study. Science 273: 1856-1862

157. Liu R, Paxton WA, Choe S, Ceradini D, Martin SR, Horuk R, MacDonald ME, Stuhlmann H, Koup RA and Landau NR (1996) Homozygous defect in HIV-1 coreceptor accounts for resistance of some multiply-exposed individuals to HIV-1 infection. Cell. 86: 367-377

158. Samson M, Libert F, Doranz BJ, Rucker J, Liesnard C, Farber CM, Saragosti S, Lapoumeroulie C, Cognaux J, Forceille C, Muyldermans G, Verhofstede C, Burtonboy G, Georges M, Imai T, Rana S, Yi Y, Smyth RJ, Collman RG, Doms RW, Vassart G and Parmentier M (1996) Resistance to HIV-1 infection in caucasian individuals bearing mutant alleles of the CCR- 5 chemokine receptor gene. Nature 382: 722-725

159. Michael NL, Chang G, Louie LG, Mascola JR, Dondero D, Birx DL and Sheppard HW (1997) The role of viral phenotype and CCR-5 gene defects in HIV-1 transmission and disease progression. Nat. Med. 3: 338-340

160. Michael NL, Louie LG, Rohrbaugh AL, Schultz KA, Dayhoff DE, Wang CE and Sheppard HW (1997) The role of CCR5 and CCR2 polymorphisms in HIV-1 transmission and disease progression. Nat. Med. 3: 1160-1162

161. Mummidi S, Ahuja SS, Gonzalez E, Anderson SA, Santiago EN, Stephan KT, Craig FE, O'Connell P, Tryon V, Clark RA, Dolan MJ and Ahuja SK (1998) Genealogy of the CCR5 locus and chemokine system gene variants associated with altered rates of HIV-1 disease progression. Nat. Med. 4: 786-793

162. de Roda Husman AM, Blaak H, Brouwer M and Schuitemaker H (1999) CC chemokine receptor 5 cell-surface expression in relation to CC chemokine receptor 5 genotype and the clinical course of HIV-1 infection. J. Immunol. 163: $4597-4603$

163. Ostrowski MA, Justement SJ, Catanzaro A, Hallahan CA, Ehler LA, Mizell SB Kumar PN, Mican JA, Chun TW and Fauci AS (1998) Expression of chemokine receptors CXCR4 and CCR5 in HIV-1-infected and uninfected individuals. J. Immunol. 161: 3195-3201
164. Reynes J, Portales $P$, Segondy M, Baillat V, Andre P, Reant B, Avinens $O$, Couderc G, Benkirane M, Clot J, Eliaou JF and Corbeau P (2000) CD4+ T cell surface CCR5 density as a determining factor of virus load in persons infected with human immunodeficiency virus type 1. J. Infect. Dis. 181: 927-932

165. Reynes J, Portales P, Segondy M, Baillat V, Andre P, Avinens O, Picot MC, Clot J, Eliaou JF and Corbeau P (2001) CD4 T cell surface CCR5 density as a host factor in HIV-1 disease progression. AIDS 15: 1627-1634

166. Veazey RS, Mansfield KG, Tham IC, Carville AC, Shvetz DE, Forand AE and Lackner AA (2000) Dynamics of CCR5 expression by CD4(+) T cells in lymphoid tissues during simian immunodeficiency virus infection. J. Virol. 74: 11001-11007

167. Veazey R, Ling B, Pandrea I, McClure H, Lackner A and Marx P (2003) Decreased CCR5 expression on CD4+ T cells of SIV-infected sooty mangabeys. AIDS Res. Hum. Retroviruses 19: 227-233

168. Krzysiek R, Rudent A, Bouchet-Delbos L, Foussat A, Boutillon C, Portier A, Ingrand D, Sereni D, Galanaud P, Grangeot-Keros L and Emilie D (2001) Preferential and persistent depletion of CCR5+ T-helper lymphocytes with nonlymphoid homing potential despite early treatment of primary HIV infection. Blood 98: 3169-3171

169. Zaunders JJ, Kaufmann GR, Cunningham PH, Smith D, Grey P, Suzuki K, Carr A, Goh LE and Cooper DA (2001) Increased turnover of CCR5+ and redistribution of CCR5- CD4 T lymphocytes during primary human immunodeficiency virus type 1 infection. J. Infect. Dis. 183: 736-743

170. Luciw PA, Pratt-Lowe E, Shaw KE, Levy JA and Cheng-Mayer C (1995) Persistent infection of rhesus macaques with T-cell-line-tropic and macrophage-tropic clones of simian/human immunodeficiency viruses (SHIV). Proc. Natl. Acad. Sci. USA 92: 7490-7494

171. Reimann KA, Li JT, Voss G, Lekutis C, Tenner-Racz K, Racz P, Lin W, Montefiori DC, Lee-Parritz DE, Lu Y, Collman RG, Sodroski J and Letvin NL (1996) An env gene derived from a primary human immunodeficiency virus type 1 isolate confers high in vivo replicative capacity to a chimeric simian/human immunodeficiency virus in rhesus monkeys. J. Virol. 70: 3198-3206

172. Shibata R, Maldarelli F, Siemon C, Matano T, Parta M, Miller G, Fredrickson T and Martin MA (1997) Infection and pathogenicity of chimeric simian-human immunodeficiency viruses in macaques: determinants of high virus loads and CD4 cell killing. J. Infect. Dis. 176: 362-373

173. Steger KK, Dykhuizen M, Mitchen JL, Hinds PW, Preuninger BL, Wallace M, Thomson J, Montefiori DC, Lu Y and Pauza CD (1998) CD4+-T-cell and CD20+-B-cell changes predict rapid disease progression after simian-human immunodeficiency virus infection in macaques. J. Virol. 72: 1600-1605

174. Harouse JM, Gettie A, Tan RC, Blanchard J and Cheng-Mayer C (1999) Distinct pathogenic sequela in rhesus macaques infected with CCR5 or CXCR4 utilizing SHIVs. Science 284: 816-819

175. Berger EA, Doms RW, Fenyo EM, Korber BT, Littman DR, Moore JP, Sattentau QJ, Schuitemaker H, Sodroski J and Weiss RA (1998) A new classification for HIV-1. Nature 391: 240

176. Marx PA and Chen Z (1998) The function of simian chemokine receptors in the replication of SIV. Semin. Immunol. 10: 215-223

177. Muller MC and Barre-Sinoussi $F$ (2003) SIVagm: genetic and biological features associated with replication. Front Biosci. 8: d1170-d1185

178. Veazey RS, Marx PA and Lackner AA (2003) Vaginal CD4+ T cells express high levels of CCR5 and are rapidly depleted in simian immunodeficiency virus infection. J. Infect. Dis. 187: 769-776

179. Picker LJ, Hagen SI, Lum R, Reed-Inderbitzin EF, Daly LM, Sylwester AW, Walker JM, Siess DC, Piatak Jr M, Wang C, Allison DB, Maino VC, Lifson JD, Kodama T and Axthelm MK (2004) Insufficient production and tissue delivery of $\mathrm{CD} 4+$ memory $T$ cells in rapidly progressive simian immunodeficiency virus infection. J. Exp. Med. 200: 1299-1314

180. Mattapallil JJ, Letvin NL and Roederer M (2004) T-cell dynamics during acute SIV infection. AIDS 18: 13-23

181. Matloubian M, David A, Engel S, Ryan JE and Cyster JG (2000) A transmembrane CXC chemokine is a ligand for HIV-coreceptor Bonzo. Nat. Immunol. 1: 298-304

182. Deng HK, Unutmaz D, KewalRamani VN and Littman DR (1997) Expression cloning of new receptors used by simian and human immunodeficiency viruses. Nature 388: 296-300

183. Alkhatib G, Liao F, Berger EA, Farber JM and Peden KW (1997) A new SIV co-receptor, STRL33. Nature 388: 238 
184. Farzan M, Choe H, Martin K, Marcon L, Hofmann W, Karlsson G, Sun Y, Barrett P, Marchand N, Sullivan N, Gerard N, Gerard C and Sodroski J (1997) Two orphan seven-transmembrane segment receptors which are expressed in CD4-positive cells support simian immunodeficiency virus infection. J. Exp. Med. 186: 405-411

185. Kimata JT, Gosink JJ, KewalRamani VN, Rudensey LM, Littman DR and Overbaugh J (1999) Coreceptor specificity of temporal variants of simian immunodeficiency virus Mne. J. Virol. 73: 1655-1660

186. Kimata JT, Kuller L, Anderson DB, Dailey P and Overbaugh J (1999) Emerging cytopathic and antigenic simian immunodeficiency virus variants influence AIDS progression. Nat. Med. 5: 535-541

187. Chen Z, Gettie A, Ho DD and Marx PA (1998) Primary SIVsm isolates use the CCR5 coreceptor from sooty mangabeys naturally infected in west Africa: a comparison of coreceptor usage of primary SIVsm, HIV-2, and SIVmac. Virology 246: 113-124

188. Owen SM, Masciotra S, Novembre F, Yee J, Switzer WM, Ostyula M and Lal RB (2000) Simian immunodeficiency viruses of diverse origin can use CXCR4 as a coreceptor for entry into human cells. J. Virol. 74 5702-5708

189. Beer BE, Foley BT, Kuiken CL, Tooze Z, Goeken RM, Brown CR, Hu J, St Claire M, Korber BT and Hirsch VM (2001) Characterization of novel simian immunodeficiency viruses from red-capped mangabeys from Nigeria (SIVrcmNG409 and -NG411). J. Virol. 75: 12014-12027

190. Petit $F$, Arnoult $D$, Viollet $L$ and Estaquier $J(2003)$ Intrinsic and extrinsic pathways signaling during HIV-1 mediated cell death. Biochimie. 85: 795-811 